\title{
A Study on the Optimization of Tax Structure from the Perspective of Economic Growth
}

\author{
Han Wu ${ }^{1}$, Ke Gao ${ }^{1}$, Ming Chen ${ }^{2}$ \\ ${ }^{1}$ The School of Public Finance and Taxation, Central University of Finance and Economics, Beijing, China \\ ${ }^{2}$ Center for China Fiscal Development, Central University of Finance and Economics, Beijing, China
}

Email address:

wuhan0130@163.com (Han Wu),gkfly@126.com (Ke Gao), Chenming_april@163.com (Ming Chen)

To cite this article:

$\mathrm{Han} \mathrm{Wu}, \mathrm{Ke}$ Gao, Ming Chen. A Study on the Optimization of Tax Structure from the Perspective of Economic Growth. International Journal of Business and Economics Research. Vol. 6, No. 5, 2017, pp. 93-99. doi: 10.11648/j.ijber.20170605.12

Received: August 10, 2017; Accepted: September 6, 2017; Published: September 14, 2017

\begin{abstract}
The institution supply is an important dimension of China's supply-side reform, in which the reform and optimization of tax system structure is an important measure to promote economic growth. This paper first reviewed the literatures about how the tax structure influences economic growth. Then, this paper used the reform of Chinese tax system as a starting point for the study, measured nearly 20 years of HP and HHI index to reflect the changes in tax structure, and analyzed the difference between the direct tax and the indirect tax on the economic growth. Finally, on the basis of the empirical conclusion of this paper, it put forward the corresponding policy suggestions.
\end{abstract}

Keywords: Tax Structure, Economic Growth, Chinese Tax System

\section{Introduction}

In the context of the "new normal" of the economy, the Outline of China's 13th Five-Year Plan of puts forward that in accordance with the requirements of optimizing the tax structure, stabilizing the macro tax burden and promoting tax administration according to law to make sure that the tax law should be fully implemented, and the establishment of a tax science, structural optimization, legal sound, standardized and fair, collection and management of modern tax system, and gradually increase the proportion of direct tax. China's entry into the "threestage superposition" of the new period, the tax structure adjustment and optimization, especially the indirect tax and direct tax ratio, the economic stability and sustainable development is of great significance. Jia Kang put forward that the direct tax and indirect tax imbalance is not conducive to economic and social transformation. China has implemented an indirect tax-based tax system for a long time. How to fundamentally adjust the tax structure and promote the economy based on the current status of over taxation in circulation has become a major problem [1].

\section{Literature Review}

The relationship between the tax structure and economic growth is a long-term concern of scholars. Cremer Helmuth, Pestieau Pierre and Rochet Jean-Charles (1999) constructs a Cobb-Dauglas production function that takes into account the productivity and factor endowments. By selecting the utility function of the difference, the optimal direct tax and indirect ratio in the form of different utility functions are obtained, and the structure of the economic growth influences [2]. Johannah Branson (2001) estimates the tax burden and taxation that maximizes economic growth rates, The average tax burden of the optimal tax burden is $22.5 \%$ for the optimal tax burden, which means that the average tax revenue is $65 \%$ of the total tax revenue, and the tax burden will increase the real GDP of $17 \%$, tax revenues decreased by $6 \%$, and private purchases increased by $27 \%$ [3]. Arnold (2008) based on panel data from 21 OECD countries, proved that the consumption tax and property tax on the role of economic growth are more significant, corporate income tax on the economy is relatively weak [4]. Ekpung and Wilfred (2014) use the Nigeria's economic data study found that corporate income tax and corporate income tax and corporate income tax Indirect taxes represented by the personal income tax are 
negatively correlated with economic growth [5]. Subramanya Venkataraman and Arabi Urmi (2017) used the time series data of 1977-2015 in India to study the relationship between direct tax, indirect tax and long-term economic growth in India which concluded that in the long term, the direct tax has no significant effect on personal income tax growth; indirect tax and consumption tax has no significant impact on economic growth; tariffs and economic growth has a significant positive correlation [6].

Chinese scholars Xia Jie-chang and Wang Xin-li (2003) analyzed China's indirect tax-based tax structure. They argued that the tax structure has a relatively limited role in stabilizing the economy and has suppressed consumption and investment [7]. Chang Shi-wang, Han Ren-yue (2015) measured the optimal tax structure of 31 provinces in China from 1996 to 2012 with the aim of maximizing economic growth. They calculated the efficiency of the region's existing tax structure. The conclusion is that the structural elasticity of taxation in 25 regions is negative, and the proportion of indirect taxes should be gradually reduced to promote economic growth. Chinese current tax structure has exacerbated regional economic disparities [8]. Ma Hai-tao, Duan Qi (2016) used the VAR model to analyze the economic efficiency of direct and indirect taxes. They found that Chinese direct tax economic efficiency is higher than the indirect tax economic efficiency [9].

From the existing literature, most of the scholars analyzed the impact of the total economic growth from the perspective of the amount of direct tax and indirect tax. However, there are few literatures analyzing the mechanism of direct tax and indirect tax influencing the economic growth. Taxation has a distorted price in the process of levying, and the effects of direct and indirect taxes on the nominal economic growth and actual economic growth are not the same. The direct tax is generally taxed according to the legal person, and the influence on price is relatively small while the indirect tax has a great influence on the economic growth through distorting the price. This paper revises the empirical study on the impact of China's tax structure on economic growth, and the relationship between structure and economic growth is reexamined.

\section{An Analysis of the Structure of Chinese Tax System}

Since the founding of New China, China has experienced five major changes in the proportion of direct tax revenue and indirect tax revenue. In 1950, there were 16 kinds of tax in China. Indirect tax only includes the goods tax, salt tax, customs duties and industrial and commercial tax. The difference between the income of the direct tax and indirect tax revenue was not significant. In 1958, after the tax reform, indirect tax revenue rose rapidly, the initial formation of China's indirect tax became the main body of the tax structure; after the 1973 tax reform, the proportion of China's indirect tax further increased from $78.9 \%$ in 1959 to $81.9 \%$; the proportion of direct tax increased to $38.9 \%$ in 1985 ; in 1994, China introduced the tax reform system, and the proportion of indirect tax was increased again due to the weak growth of corporate income tax paid by state-owned enterprises and collective enterprises. From the perspective of welfare economics, combined with the development process of the reform of China's tax system, the tax structure with the simple direct tax as the main body at the beginning of the founding of the People's Republic of China focuses on the fair dimension of welfare economics; the tax structure of the second stage indirect tax, focusing on the efficiency of welfare economics dimensions; the tax structure since the tax-share system, taking into account the efficiency and fairness at the same time, the adjustment of the tax structure to focus on taxpayers more freedom of choice. From fair to efficient, and then to the free tax reform process is the embodiment of economic development. In order to analyze the influence of tax structure on economic growth, this paper needs to classify the direct tax and indirect tax, and refer to Li Hua, Fan Li-ming (2015), the current tax levied in China in accordance with the direct tax and indirect tax are showed in Table 1 [10].

Table 1. Tax classification table.

\begin{tabular}{ll}
\hline Classification criteria & Taxes included \\
\hline Indirect tax & Value-added tax, consumption tax, business tax, tariff, vehicle purchase tax, tobacco tax, city maintenance and \\
& construction tax, resource tax, environmental tax (will be levied) \\
& $\begin{array}{l}\text { Personal income tax, corporate income tax, payroll tax (social insurance contribution), property tax, Urban land use tax, } \\
\text { travel tax, land value added tax, deed tax, stamp duty, arable land occupation tax, Banquet tax (canceled), agricultural tax } \\
\text { (canceled), fixed asset direction adjustment tax (suspended), ship tons tax }\end{array}$ \\
\hline
\end{tabular}

According to this classification standard, the proportion of direct tax and indirect tax in China from 1997 to 2016 is shown in Table 2. On the basis of the payroll tax (social insurance contribution), it can be seen from Table 2 that the proportion of indirect tax in China's total tax revenue has been declining in the past 20 years, and the proportion of direct tax has increased steadily.

The tax structure is usually reflected by the annual change in the tax structure and the concentration of the tax system, respectively, from the Hymer Pashigian's Mobility Index and the HHI (Herfindahl Hirschman Index). In the study of the direct tax and the proportion of indirect tax changes, $t$ represents the year, $R_{d, t}$ represents the share of the direct tax $t$ year in the total tax revenue; $R_{i, t}$ represents the share of indirect tax $t$ year in total tax revenue. $0 \leq \mathrm{R}_{\mathrm{d}, \mathrm{t}}, \mathrm{R}_{\mathrm{i}, \mathrm{t}} \leq 1$, and $\mathrm{R}_{\mathrm{d}, \mathrm{t}}+\mathrm{R}_{\mathrm{i}, \mathrm{t}}=1$. HP Mobility Index $\Delta \mathrm{R}_{\mathrm{t}}=\left|\mathrm{R}_{\mathrm{d}, \mathrm{t}}-\mathrm{R}_{\mathrm{d}, \mathrm{t}-1}\right|+\left|\mathrm{R}_{\mathrm{i}, \mathrm{t}}-\mathrm{R}_{\mathrm{i}, \mathrm{t}-1}\right|$, When the HP index is larger, the greater the change in the tax structure, the smaller the HP index, the smaller the change in the tax structure. On this basis, the HHI index $S=R_{d, t}^{2}+R_{i, t}^{2}$. When the HHI index is larger, the greater the concentration 
of the tax structure is, the smaller the HP index is, the smaller the tax structure is. According to the above algorithm, the HP index and the HHI index (see Table 3 and Table 4) of the change of China's tax structure in 1997-2016 are obtained.

Table 2. Chinese direct tax and indirect tax revenue in 1997 - 2016 unit: \%.

\begin{tabular}{|c|c|c|c|c|c|c|c|c|c|c|}
\hline Year & 1997 & 1998 & 1999 & 2000 & 2001 & 2002 & 2003 & 2004 & 2005 & 2006 \\
\hline The proportion of direct tax & 35.94 & 34.98 & 35.31 & 36.05 & 40.43 & 42.18 & 39.89 & 39.47 & 40.83 & 42.33 \\
\hline The proportion of indirect tax & 67.02 & 69.06 & 63.88 & 60.96 & 53.95 & 57.92 & 59.17 & 57.65 & 55.69 & 54.18 \\
\hline Year & 2007 & 2008 & 2009 & 2010 & 2011 & 2012 & 2013 & 2014 & 2015 & 2016 \\
\hline The proportion of indirect tax & 50.6 & 50.34 & 50.39 & 51.56 & 49.88 & 48.41 & 46.34 & 44.79 & 41.56 & 56.24 \\
\hline
\end{tabular}

Notes: 1. Source: According to the National Bureau of Statistics 1998 - 2017 data, "China Tax Yearbook" 1997 - 2014 annual data calculated.

2. "Taxation of China Tax Yearbook" The tax revenue data sheet "Other taxes" as a result of the tax is not clear, so it is not divided. In order to keep the data caliber consistent, the stamp duty on securities transactions will be classified as stamp duty.

Table 3. 1997 - 2016 Chinese Tax Structure HP Index.

\begin{tabular}{|c|c|c|c|c|c|c|c|c|c|c|}
\hline Year & 1997 & 1998 & 1999 & 2000 & 2001 & 2002 & 2003 & 2004 & 2005 & 2006 \\
\hline HP Index & 0.032 & 0.019 & 0.007 & 0.015 & 0.088 & 0.035 & 0.046 & 0.008 & 0.027 & 0.03 \\
\hline Year & 2007 & 2008 & 2009 & 2010 & 2011 & 2012 & 2013 & 2014 & 2015 & 2016 \\
\hline HP Index & 0.052 & 0.016 & 0 & 0.021 & 0.023 & 0.024 & 0.045 & 0.043 & 0.056 & 0.038 \\
\hline
\end{tabular}

Source: Measured according to National Bureau of Statistics 1997 - 2016.

Table 4. 1997 - 2016 Chinese Tax Structure HHI Index.

\begin{tabular}{|c|c|c|c|c|c|c|c|c|c|c|}
\hline Year & 1997 & 1998 & 1999 & 2000 & 2001 & 2002 & 2003 & 2004 & 2005 & 2006 \\
\hline HHI Index & 0.54 & 0.545 & 0.543 & 0.539 & 0.518 & 0.512 & 0.52 & 0.522 & 0.517 & 0.512 \\
\hline Year & 2007 & 2008 & 2009 & 2010 & 2011 & 2012 & 2013 & 2014 & 2015 & 2016 \\
\hline HHI Index & 0.505 & 0.504 & 0.504 & 0.506 & 0.503 & 0.502 & 0.5 & 0.5 & 0.504 & 0.508 \\
\hline
\end{tabular}

Source: Measured according to National Bureau of Statistics 1997 - 2016.

Currently, the focus and difficulties of Chinese tax reform are on the direct tax, and the ratio of direct and indirect taxes is still uncoordinated. If the payroll tax is not considered (social security contributions), $70 \%$ of Chinese current tax revenue comes from the indirect tax, one of the characteristics of indirect tax is that it can pass the tax amount through the commodity price channels which have three elements: profits, interests, and tax. China's current commodity production and circulation links, the taxes involved are mostly indirect taxes and the price when the middle of the larger tax, so as the main source of tax revenue in China has a greater role in the distortion of the price, so the analysis of the price factor before and after the tax structure the impact on economic growth is necessary.

\section{Empirical Analysis}

As a systematic factor, China's current tax structure influences the economic growth mainly by influencing the price. If the price can promote the optimal allocation of resource allocation, it will be able to accurately reflect the market supply and demand situation, but also reflects the allocation of resources. Therefore, considering the price factors, when it comes to the economic growth, firstly, distinguish between nominal growth and real growth are important; in considering the impact of economic growth, the core elements, should also distinguish between nominal and actual amount. In this paper, the nominal variables and the real variables were used to measure the difference between the price factors before and after the tax structure on the economic growth of the differences.

A. Model building

This paper introduces tax variables based on the CobbDouglas production function, $\mathrm{Y}=\mathrm{F}(\mathrm{A}, \mathrm{L}, \mathrm{K})=\mathrm{AL}^{\alpha} \mathrm{K}^{\beta}$. Where $\mathrm{Y}$ is the economic growth variable, $\mathrm{L}$ is the labor variable, $\mathrm{K}$ is the capital variable, $\mathrm{F}$ is the institutional variable, $\mathrm{A}$ is the technological progress variable.

Considering the factors of tax structure, assume that the tax structure is in the form of a constant, and Each production cycle is born out of the Cobb-Douglas production function, then there is equation (1), where e is a natural logarithm, db is the proportion of the direct tax revenue to the total tax revenue, $i b$ is the proportion of the indirect tax revenue to the total tax revenue.

$$
Y=F(A, L, K)=A L^{\alpha} K^{\beta} e^{d b / i b}
$$

Equation (4-1) is linearly developed to give the equation (2).

$$
\mathrm{LNY}=\mathrm{LNA}+\alpha \mathrm{LNL}+\beta \mathrm{LNK}+\mathrm{db} / \mathrm{ib}
$$

This paper argues that LNY can measure the continuous dynamic change of economic growth, and can eliminate heteroskedasticity and autocorrelation in econometrics. On the basis of equation (2), it is considered that the effect of tax structure change on economic growth rate, LNA, LNL, LNK, respectively, reflect the technical, labor and capital of the continuous dynamic changes. As the variable LNA is not easy to measure, this paper used the processing method adopted in the Solow economic growth model to classify the other factors including LNA into the constant term. This 
paper based on the tax structure of Chang Shiwang, Han Renyue as a measure of the structure of the tax system [8], which is derived from Table 2 for the year 1996 to 2015. The use of the direct tax ratio / indirect tax ratio $(\mathrm{db} / \mathrm{ib})$ as a measure of the tax structure The value of the direct tax proportion / indirect tax is defined as one of the variables that explain economic growth and is converted to equation (3) on the basis of equation (2), where $a_{0}$ is constant, and $a_{1}, a_{2}, a_{3}$ is the elastic coefficient of each variable to economic growth rate, and $\varepsilon$ is the residual term.

$$
\text { LNY }=a_{0}+a_{1} L N L+a_{2} L N K+a_{3}(d b / i b)+\varepsilon
$$

B. Variables and data

This paper used the annual nominal GDP as the Economic Growth Variables $\mathrm{Y}$, and the labor force variable $\mathrm{L}$ is the total number of national employed persons and the nominal per capita disposable income. This variable can reflect the value of labor in economic growth. The capital variable $\mathrm{K}$ is the nominal value of the total investment in fixed assets. This variable reflects the value of capital investment in the year.

Table 5. Standard Table of Variables for 1996- 2015.

\begin{tabular}{|c|c|c|c|c|}
\hline Year & Nominal GDP (100 million Yuan) & $\begin{array}{l}\text { Nominal labor value investment } \\
\text { (100 million Yuan) }\end{array}$ & $\begin{array}{l}\text { Nominal capital value } \\
\text { investment ( } 100 \text { million Yuan) }\end{array}$ & Direct tax / indirect tax (\%) \\
\hline 1996 & 71813.60 & 19631.30 & 22913.50 & 0.60 \\
\hline 1997 & 79715.00 & 21734.18 & 24941.10 & 0.56 \\
\hline 1998 & 85195.50 & 23430.07 & 28406.20 & 0.54 \\
\hline 1999 & 90564.40 & 25313.57 & 29854.70 & 0.55 \\
\hline 2000 & 100280.10 & 27424.44 & 32917.70 & 0.56 \\
\hline 2001 & 110863.10 & 30029.86 & 37213.49 & 0.68 \\
\hline 2002 & 121717.40 & 33662.20 & 43499.91 & 0.73 \\
\hline 2003 & 137422.00 & 37404.70 & 55566.61 & 0.66 \\
\hline 2004 & 161840.20 & 42498.34 & 70477.43 & 0.65 \\
\hline 2005 & 187318.90 & 48462.25 & 88773.61 & 0.69 \\
\hline 2006 & 219438.50 & 55030.23 & 109998.16 & 0.73 \\
\hline 2007 & 270232.30 & 65561.06 & 137323.94 & 0.82 \\
\hline 2008 & 319515.50 & 76575.54 & 172828.40 & 0.84 \\
\hline 2009 & 349081.40 & 84986.60 & 224598.77 & 0.84 \\
\hline 2010 & 413030.30 & 98044.26 & 251683.77 & 0.81 \\
\hline 2011 & 489300.60 & 114583.61 & 311485.13 & 0.85 \\
\hline 2012 & 540367.40 & 131504.63 & 374694.74 & 0.89 \\
\hline 2013 & 595244.40 & 145204.33 & 446294.09 & 0.98 \\
\hline 2014 & 643974.00 & 160711.78 & 512020.65 & 1.06 \\
\hline 2015 & 685505.80 & 175929.41 & 561999.83 & 1.19 \\
\hline
\end{tabular}

Source: China Statistical Yearbook (2016) and the author projections, the direct tax / indirect tax value of the decimal point after the two.

In the time series regression process, in order to avoid pseudo-regression, we need to test the unit root for each variable. In this paper, the unit mean value of LNY, LNL, LNK and $\mathrm{db} / \mathrm{ib}$ were tested. The results showed that the original sequence of the four variables rejected the original hypothesis at the 5\% significance level, so the sequence was non-stationary. The sequence after the stepwise difference treatment is a stationary sequence at the significance level of $5 \%$, so each variable obeys the second order stationary, so it may have the co integration relation.

Using the above nominal variable, the OLS regression is performed using the econometric equation of equation (3) in the Stata 12 environment. The results of the co-integration regression equation are shown in equation (4).

$$
\begin{gathered}
\mathrm{LNY}=1.660322+0.691248 \mathrm{LNL}+0.280568 \mathrm{LNK}- \\
0.223312(\mathrm{db} / \mathrm{ib})
\end{gathered}
$$

The specific regression results are shown in Table 6, adjusted $\mathrm{R}^{2}$ value of 0.999001 , the linear fit of the equation is very good. LNG, LNK, $\mathrm{db} / \mathrm{ib} \mathrm{t}$ statistics are greater than $5 \%$ critical level, indicating that the estimated value of its parameters is significant. An F value of 6336.662, indicating a higher degree of model fits. DW value is close to 2 , indicating that the residual sequence of the model has no

\begin{tabular}{|c|c|c|c|c|}
\hline Variable & Regression coefficients & Standard deviation & T value & P value \\
\hline $\mathrm{C}$ & 1.660322 & 0.605572 & 2.741740 & 0.0145 \\
\hline LNL & 0.691248 & 0.164542 & 4.201029 & 0.0007 \\
\hline LNK & 0.280568 & 0.102106 & 2.747804 & 0.0143 \\
\hline $\mathrm{db} / \mathrm{ib}$ & -0.223312 & 0.095442 & -2.339763 & 0.0326 \\
\hline $\mathrm{R}^{2}$ & 0.999159 & & Adjust $\mathrm{R}^{2}$ & 0.999001 \\
\hline $\mathrm{F}$ value & 6336.662 & & DW value & 1.234086 \\
\hline$P$ value & 0.000000 & & Number of samples & 20 \\
\hline
\end{tabular}
autocorrelation.

Table 6. Nominal variable regression results.

Source: Stata 12 Statistics Finished. 
Table 7. Nominal variable regression residual unit root test.

\begin{tabular}{llll}
\hline & & T value & P value \\
\hline ADF test statistic & & -3.53549 & 0.0014 \\
& $1 \%$ & -2.69977 & - \\
Check the critical value & $5 \%$ & -1.96141 & - \\
& $10 \%$ & -1.60661 & - \\
\hline
\end{tabular}

Source: Stata 12 Statistics Finished.

In this paper, the Engle-Granger method is used to estimate the residual term of the long-term equilibrium equation estimated by OLS regression method. The results are shown in Table 7, and the $\mathrm{P}$ value is significant at $1 \%$ level. The variables have co integration relationship, and did not produce pseudo-regression results.

Taking into account inflation and other factors, this paper measures the real GDP, labor value input and capital value investment after 1990, the actual value of the specific variables were shown in Table 8.

Table 8. Table of Actual Values for Variables for 1996- 2015.

\begin{tabular}{|c|c|c|c|c|}
\hline Year & Real GDP (100 million Yuan) & $\begin{array}{l}\text { Actual labor value investment } \\
\text { (100 million Yuan) }\end{array}$ & $\begin{array}{l}\text { Actual capital value investment } \\
\text { (100 million Yuan) }\end{array}$ & Direct tax / indirect tax \\
\hline 1996 & 36989.28 & 12359.19 & 8776.53 & 0.60 \\
\hline 1997 & 40403.67 & 13700.32 & 8925.59 & 0.56 \\
\hline 1998 & 43570.36 & 15042.66 & 8912.04 & 0.54 \\
\hline 1999 & 46911.11 & 16354.23 & 8875.91 & 0.55 \\
\hline 2000 & 50894.57 & 18009.37 & 8970.76 & 0.56 \\
\hline 2001 & 55139.13 & 19539.86 & 9006.90 & 0.68 \\
\hline 2002 & 60173.69 & 21468.07 & 9024.97 & 0.73 \\
\hline 2003 & 66212.48 & 23755.39 & 9223.71 & 0.66 \\
\hline 2004 & 72907.37 & 26289.69 & 9743.17 & 0.65 \\
\hline 2005 & 81215.73 & 29608.45 & 9896.75 & 0.69 \\
\hline 2006 & 91545.95 & 33459.99 & 10045.81 & 0.73 \\
\hline 2007 & 104574.21 & 38329.99 & 10438.79 & 0.82 \\
\hline 2008 & 114670.11 & 42313.31 & 11373.81 & 0.84 \\
\hline 2009 & 125448.88 & 46569.46 & 11102.79 & 0.84 \\
\hline 2010 & 138791.80 & 52106.28 & 11500.28 & 0.81 \\
\hline 2011 & 152027.60 & 57214.44 & 12259.14 & 0.85 \\
\hline 2012 & 163971.29 & 61956.73 & 12394.65 & 0.89 \\
\hline 2013 & 176691.58 & 67106.68 & 12430.78 & 0.98 \\
\hline 2014 & 189585.95 & 72358.02 & 12494.02 & 1.06 \\
\hline 2015 & 202694.54 & 77750.37 & 12268.17 & 1.19 \\
\hline
\end{tabular}

Source: China Statistical Yearbook (2016) and the author projections, the direct tax / indirect tax value of the decimal point after the two.

In this paper, the unit values of LNY, LNL, LNK and $\mathrm{db} /$ $\mathrm{ib}$ were tested. The results showed that the original sequence of the four variables rejected the original hypothesis at the $5 \%$ significance level, and the sequence was non-stationary. The sequence after the stepwise difference treatment is a stationary sequence at the significance level of $5 \%$, so each variable obeys the second order single product, so it may have the co integration relation.

Using the above-mentioned actual value variables, OLS regression was performed using the equation of equation (3) in the Stata 12 environment. The results of the co integration regression equation are shown in equation (5).

$$
\begin{array}{r}
\mathrm{LNY}=0.477965+0.879294 \mathrm{LNL}+0.189421 \mathrm{LNK}+ \\
0.047981(\mathrm{db} / \mathrm{ib})
\end{array}
$$

Specific regression results shown in Table 9, adjust the $\mathrm{R}^{2}$ value of 0.999943 , the linear fit of the equation is high. LNG, LNK, $\mathrm{db} / \mathrm{ib} \mathrm{t}$ statistics are greater than $5 \%$ critical level, indicating that the estimated value of its parameters is significant. An F value of 105067.8, indicating a higher degree of model fits. DW value is close to 2 , indicating that the residual sequence of the model has no autocorrelation.

Table 9. Real variable regression results.

\begin{tabular}{lllll}
\hline Variable & Regression coefficients & S.e. & T value & P value \\
\hline $\mathrm{C}$ & 0.477965 & 0.232682 & 2.054159 & 0.0567 \\
$\mathrm{LNL}$ & 0.879294 & 0.008975 & 97.97523 & 0.0000 \\
$\mathrm{LNK}$ & 0.189421 & 0.033455 & 5.662002 & 0.0000 \\
$\mathrm{db} / \mathrm{ib}$ & 0.047981 & 0.015405 & 3.114554 & 0.0067 \\
$\mathrm{R}^{2}$ & 0.999944 & & Adjust $^{2}$ & 0.999934 \\
$\mathrm{~F}$ value & 96003.37 & & DW value & 1.460162 \\
$\mathrm{P}$ value & 0.000000 & & Number of samples & 20 \\
\hline
\end{tabular}

Source: Stata 12 Statistics Finished.

For the test of the real variables, the Engle-Granger method is used to estimate the residual term of the long-term equilibrium equation estimated by the OLS regression method. The test results are shown in Table 10, and the $\mathrm{P}$ value is 
significant at the $1 \%$ level. The variables have a co integration relationship and do not produce pseudo-regression results.

Table 10. Real variable regression residual unit root test.

\begin{tabular}{llll}
\hline & t value & P value \\
\hline ADF test statistic & & -3.74858 & 0.0008 \\
& $1 \%$ & -2.692358 & - \\
Check the critical value & $5 \%$ & -1.960171 & - \\
& $10 \%$ & -1.607051 & - \\
\hline
\end{tabular}

Source: Stata 12 Statistics Finished.

From the result of the regression of the nominal variable (4), the growth rate of labor value investment increased by $1 \%$, the economic growth rate increased by $0.69 \%$; the capital value input growth rate increased by $1 \%$, the economic growth rate increased by $0.28 \%$; direct tax / indirect tax reflects the change in tax system, when its change $1 \%$, the economic growth rate fell $0.22 \%$. The results show that the increase in the proportion of direct tax does not eliminate the price factor, which may be due to the fact that the enterprise income tax and personal income tax are the main ones in the direct tax, and the enterprise income tax and personal income tax are affected by the price.

From the regression of the real variable (5), labor value growth rate increased by $1 \%$, economic growth rate increased by $0.88 \%$; capital value growth rate increased by $1 \%$, economic growth rate increased $0.19 \%$; direct tax / indirect tax ratio of $1 \%$, the economic growth rate increased by $0.05 \%$. The measurement results show that the increase in the proportion of the direct tax burden on the labor force is reflected in the elimination of the price factor and the elimination of the monetary illusion, which contributes to the increase in the working hours of the labor force to a certain extent. With the decline in the proportion of indirect taxes, the cost of consumption and the use of goods in production and life are decreasing. From the perspective of capital, the increase in the proportion of direct taxes may be due to the expansion of the direct tax base represented by corporate income tax as the representative of the decline in the proportion of indirect taxes to reduce the enterprise in the product circulation link tax burden, enterprises can be in a better economic environment, so the direct tax / indirect tax changes in the economic growth rate has a positive impact.

The difference between the nominal variable and the real variable reflects that the tax structure has a high proportion in the price structure. The tax structure with the indirect tax as the main body promotes the increase of the nominal value of the economic growth. However, from the situation that the actual value reflects, taxation in the process of commodity goods flow, the role of distortions on the price, increasing the cost of commodity goods turnover.

\section{Conclusions and Suggestion}

In the context of the current "supply side" fiscal reform, the direction of Chinese tax structure optimization is to promote the tax system from the single tax structure with indirect tax as the main body to the direct tax and indirect tax structure to promote the human capital elements, material capital Elements of the effective allocation, efforts to reduce corporate tax burden. Based on the above empirical results and the current trend of reform, this paper puts forward some policy suggestions from the perspective of direct tax and indirect tax.

A. Optimize the design of indirect taxes, and effectively reduce the survival costs of enterprises and individuals.

At present, the tax structure with indirect tax as the main body still has a certain role in promoting the economy, but it has strong regressive nature, and the indirect tax is more taxable in the production process. The price can hardly promote the effective allocation of resources. Indirect tax optimization should be reflected in the following aspects: First, continue to implement the comprehensive reform of "replacing business tax with value-added tax". The reform and value-added tax deduction chain could avoid repeated taxation effectively. The current VAT levy rate and tax rate level are still large, including 3\%, 6\%, 11\%, 17\% four categories. The gap between the tax burden in the industry is large, the value-added tax rate and tax rate level to be reduced, followed by the current tax system on the definition of modern service industry is not clear enough to further the full implementation of the "battalion" process to be improved; second, improve the value-added tax, consumption tax and other indirect tax legislation, rose to a high tax law. In the current tax system in China, the tax laws that belong to the legal form are only the Individual Income Tax Law of the People's Republic of China, the Enterprise Income Tax Law of the People's Republic of China, the Travel Tax Law of the People's Republic of China, the Environmental Protection Tax Law of the People's Republic of China, The People's Republic of China tax collection management law, involving specific taxes legislation only the first four, involving mostly direct tax. Tax system Legislation level can regulate tax collection and management, improve corporate and individual tax compliance, and reduce tax losses; third, the taxation scope of the consumption tax needs to be expanded. In addition to the current consumption tax scope, other highend consumer goods should be included, such as luxury bags, mobile phones, computers, cameras, so that the associated high-income people in fact to include high consumption tax price.

B. Deepen the personal income tax system.

The current personal income tax in China is levied on the basis of income, and it should put more emphasis on fairness, such as the ability of different individuals to pay, or health education and other living expenses and the survival costs of different families. In addition, the current personal income tax system listed in 11 individuals' taxable income, and cannot contain all the individual income sources. Building a more perfect personal income tax system requires the taxation departments have higher tax collection and management capacity. As the tax department improves the collection and management capacity and the tax priority adjustment from direct tax to the personal income tax system, 
it should be considered to gradually expand the scope of the personal income tax.

C. Optimize the design of corporate income tax system.

The current "supply side reform" put forward "mass entrepreneurship and innovation". From the government point of view, entrepreneurship and business innovation need to provide high-quality soil, just as "the first spring after the harvest", in the early stages of business growth, for nonresident enterprises, qualified small-scale low-profit enterprises, the state needs to focus on supporting high-tech enterprises. There should be a corresponding corporate income tax incentives, focusing on future tax revenue growth, and corporate income tax system can be based on industry differences, differences in profits, factors and other factors to consider, to encourage enterprises to eliminate inferior products or investment goods in the process of accelerated depreciation in the demand for technological breakthroughs, to explore the growth potential of enterprises, for enterprises in the field of R \& D undistributed profits in the tax base to a greater degree of credit to promote business research and development.

E. Further implementation of social security "fee to tax".

According to the international experience, the British, the United States, Japan, France, social security contributions is an important part of its direct tax, and social security "tax reform", which is both a good organization of fiscal revenue, but also can play a better adjustment of income distribution uneven problem, could regulate Chinese current social security system. Social security "tax reform" can be considered to offset the inflation to bring the actual income of the damage.

F. Introduce the Inheritance tax to adjust the wealth gap among families.

Based on the goal of fair multi-dimensional expansion, China should levy inheritance tax as soon as possible. Fairness includes not only fairness of results, but also fairness of chance and process. Inheritance tax is a direct tax, which is the most cost-effective and equitable process.
Inheritance tax is an important tool for the government to promote the process of marketization.

\section{References}

[1] Jia Kang, Cheng Yu. The current tax system and the new issue of a new round of tax reform [J]. Financial Market Research, 2015, 01: 4-11.

[2] Cremer H, Pestieau P, Jean-Charles Rochet. Direct Versus Indirect Taxation: The Design of the Tax Structure Revisited [J]. International Economic Review, 2001, 42(3): 781-799.

[3] Branson J, Lovell C A K. A Growth Maximising Tax Structure for New Zealand $[\mathrm{J}]$. International Tax \& Public Finance, 2001, 8(2): 129-146.

[4] Jens Arnold. Do Tax Structures Affect Aggregate Economic Growth?: Empirical Evidence from a Panel of OECD Countries. OECD Economics Department Working Papers, No. 643, 2008.

[5] Edame G E, Okoi W W. The Impact of Taxation on Investment and Economic Development in Nigeria [J]. British Journal of Surgery, 2014, 65(9): 597-600.

[6] Venkataraman S, Urmi A. The impact of taxation on economic growth in India: A disaggregated approach using the ARDL bounds test to co-integration [J]. 2017(1): 19-21.

[7] Xia Jie-chang and Wang Xin-li. The Negative Effects of Macro Tax Burden and Tax Structure on Economic Growth [J]. Tax Research, 2003, (4): 13-17.

[8] Chang shi-wang, Han ren-yue. The optimization of tax system structure from the perspective of economic growth [J]. Tax Research. 2015 (1): 54-57.

[9] Ma Hai-tao, Duan Q. Reconstruction of Tax System in the Background of Financial Reform in "Supply Side" [J]. Journal of Suzhou University (Philosophy and Social Sciences), 2016, (3): 100-109.

[10] Li Hua, Fan Liming. Research on the Direction and Path of Optimizing China 's Tax Structure $[\mathrm{M}]$. China Financial and Economic Publishing House. 2015(7): 3-5. 